\title{
Degradation Reactions in SONY-Type Li-Ion Batteries
}

\author{
E. Peter Roth, G. Nagasubramanian
}

Sandia National Laboratories, PO Box 5800 MS0613, Albuquerque, NM 87185

\begin{abstract}
Thermal instabilities were identified in SONY-type lithium-ion cells and correlated with interactions of cell constituents and reaction products. Three temperature regions of interaction were identified and associated with the state of charge (degree of $\mathrm{Li}$ intercalation) of the cell. Anodes were shown to undergo exothermic reactions as low as $100^{\circ} \mathrm{C}$ involving the solid electrolyte interface (SEI) layer and the $\mathrm{LiPF}_{6}$ salt in the electrolyte (EC:PC:DEC/LiPF 6 ). These reactions could account for the thermal runaway observed in these cells beginning at $100^{\circ} \mathrm{C}$. Exothermic reactions were also observed in the $200^{\circ} \mathrm{C}-300^{\circ} \mathrm{C}$ region between the intercalated lithium anodes, the $\mathrm{LiPF}_{6}$ salt $_{2}$ and the PVDF. These reactions were followed by a hightemperature reaction region, $300^{\circ} \mathrm{C}-400^{\circ} \mathrm{C}$, also involving the PVDF binder and the intercalated lithium anodes. The solvent was not directly involved in these reactions but served as a moderator and transport medium. Cathode exothermic reactions with the PVDF binder were observed above $200^{\circ} \mathrm{C}$ and increased with the state of charge (decreasing Li content). This offers an explanation for the observed lower thermal runaway temperatures for charged cells.
\end{abstract}

\section{INTRODUCTION}

Lithium-ion batteries (organic liquid electrolyte) are an advanced battery chemistry that exhibits superior performance characteristics to virtually all other rechargeable battery systems. The safety and reliability of these systems are of importance and thus, the interaction of the system components must be considered. Reports of decomposition of the Poly(vinylidene fluoride) (PVDF) binder component at the cathode as well as highly exothermic reactions leading to loss of battery integrity raise questions as to the fundamental compatibility of these polymers with typical cell materials [1]. The stability of optimum cell structures were studied and the fundamental material interactions characterized.

PVDF is often used as a binder in cathode and anode electrodes. The monomeric structure of the PVDF is given below.

$$
-\left(\mathrm{CH}_{2}-\mathrm{CF}_{2}\right)-
$$

$\mathrm{X}$

It is known that these polymers can undergo highly exothermic decomposition reactions (a dehydrodefluorination type reaction). In these battery systems, lithium hexafluorophosphate $\left(\mathrm{LiPF}_{6}\right)$ is used as the salt. The question of the reactivity and stability characteristics of PVDF in the presence of this salt and its decomposition products are not well understood. In the presence of the solvents typically used in these batteries, the exothermic nature of the reactions can lead to thermal runaway. The state of charge of the cell also greatly affects the thermal stability of the cell. Cells in the fully charged state exhibit lower thermal runaway temperatures and greater reactivity [2].

In this work cell materials corresponding to those used in the commercial SONY US18650 lithium-ion cell were investigated for thermal and chemical stability under charge/discharge conditions. The "as received" electrodes were initially received as sheets of current collector, 


\section{DISCLAIMER}

This report was prepared as an account of work sponsored by an agency of the United States Government. Neither the United States Government nor any agency thereof, nor any of their employees, make any warranty, express or implied, or assumes any legal liability or responsibility for the accuracy, completeness, or usefulness of any information, apparatus, product, or process disclosed, or represents that its use would not infringe privately owned rights. Reference herein to any specific commercial product, process, or service by trade name, trademark, manufacturer, or otherwise does not necessarily constitute or imply its endorsement, recommendation, or favoring by the United States Government or any agency thereof. The views and opinions of authors expressed herein do not necessarily state or reflect those of the United States Government or any agency thereof. 


\section{DISCLAIMER}

Portions of this document may be illegible in electronic image products. Images are produced from the best available original document. 
aluminum for the cathode and copper for the anode, with coatings of active material on one or both sides. The SONY-type cells consist of $\mathrm{Li}_{x} \mathrm{CoO}_{2}$ as the active cathode material and $\mathrm{Li}_{\mathrm{x}} \mathrm{C}_{6}$ (MCMB 2528 carbon) as the active anode material. Sheets of anode material of $70 \mu \mathrm{m}$ thickness $\left(9.4 \mathrm{mg} / \mathrm{cm}^{2}\right)$ were prepared on $25 \mu \mathrm{m}$ copper foil while the two-sided cathode material of $140 \mu \mathrm{m}$ total thickness $\left(18.9 \mathrm{mg} / \mathrm{cm}^{2}\right.$ per side) was prepared on $20 \mu \mathrm{m}$ aluminum foil. $\mathrm{KS}-6$ graphite (5 wt $\%$ ) was added to the cathode oxide to increase conductivity. The anode films were prepared with $10 \mathrm{wt} \%$ PVDF as the binder using $\mathrm{N}$-methyl pyrrolidinone (NMP) as a solvent during the coating process while the cathode films were prepared with $5 \mathrm{wt} \%$ PVDF. The electrolyte (EM Industries, Inc.) consisted of ethylene carbonate (EC): propylene carbonate (PC): diethyl carbonate (DEC) (1:1:2 by weight) with $1.0 \mathrm{M} \mathrm{LiPF}_{6}$ as the salt. The electrode reactions are:

$$
\begin{array}{lll}
\text { Cathode } & \mathrm{Li}_{1.0} \mathrm{CoO}_{2} & \stackrel{\text { charge }}{\longrightarrow} \mathrm{Li}_{1-\mathrm{y}} \mathrm{CoO}_{2}+\mathrm{yLi}^{+}+\mathrm{ye} \\
\text { Aischarge } & \\
& 6 \mathrm{C}+\mathrm{yLi}^{+}+\mathrm{ye} & \longrightarrow \\
\text { Overall } & \mathrm{Li}_{1.0} \mathrm{CoO}_{2}+6 \mathrm{C} \stackrel{\longrightarrow}{\longrightarrow} \longrightarrow \mathrm{Li}_{6} \\
\longrightarrow & \mathrm{Li}_{6}+\mathrm{Li}_{1-y} \mathrm{CoO}_{2}
\end{array}
$$

The range of stability of the $\mathrm{Li}_{\mathrm{x}} \mathrm{CoO}_{2}$ crystal structure limits the charged state of the cathode to about $\mathrm{x}=0.5$, giving a nominal composition of $\mathrm{Li}_{0.5} \mathrm{CoO}_{2}$ for the fully charged cathode $[3,4]$. The potential of the fully charged cathode referenced to $\mathrm{Li}_{\mathrm{Li}}{ }^{+}$is $4.1 \mathrm{~V}$ while that in the discharged state $\left(\mathrm{Li}_{1.0} \mathrm{CoO}_{2}\right)$ is $3.0 \mathrm{~V}$. The corresponding potential of the fully charged anode $\left(\mathrm{Li}_{1.0} \mathrm{C}_{6}\right)$ is $0.0 \mathrm{~V}$ and $3.0 \mathrm{~V}$ in the discharge state $\left(\mathrm{Li}_{0.0} \mathrm{C}_{6}\right)$.

\section{EXPERIMENT}

\section{Experimental Plan}

The thermal stability of the electrode components was investigated using Differential Scanning Calorimetry (DSC). Calorimetric techniques have been shown to be very useful in the characterization of these types of cells [4-8]. The cell components were characterized singly and in various combinations. Particular attention was given to interactions with the EC:PC:DEC

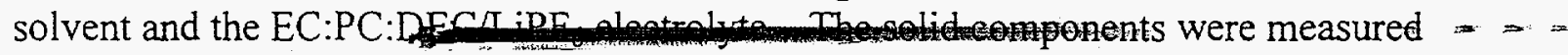
individually both in a dry state and in the presence of the solvent/electrolyte. The "as received" electrode sheet material were also measured with and without the presence of the solvent/electrolyte to check for any processing effects. Next, the electrodes were individually cycled and placed in a state of known charge (known Li content). The state of charge is known to significantly affect the thermal activity of the cell. It is important to understand how the anode and cathode contribute individually to the thermal activity of the cell under varying states of charge and which cell components are participating in these thermal reactions. The electrodes were cycled in a half-cell apparatus, removed, rinsed with DEC to remove the electrolyte and then vacuum dried. These "rinsed/dried" electrodes were then measured in the dry state, followed by measurement in the presence of the solvent and finally in the presence of the solvent/salt electrolyte. All measurements were performed in sealed DSC pans from ambient temperature up to $400^{\circ} \mathrm{C}$. 


\section{Experimental Apparatus}

Electrodes were cycled using a "T-cell" apparatus. Discs of the electrode material $(0.5$ in diameter) were cut from the electrode sheets and held by spring tension in the T-cell. Lithium foil was used as the working and reference electrodes. The cells were cycled using an Arbin battery test system (Arbin Corp., College Station, TX). Electrodes were cycled repeatedly (at least five times) at low current rate $\left(0.4 \mathrm{mamps} / \mathrm{cm}^{2}\right)$ to allow for irreversible lithium uptake in the "as manufactured" films. Only electrodes exhibiting near 100\% charge/discharge coulombic efficiency were used for further analysis. Lithium levels were set by direct coulombic measurement using the coulombic baseline between maximum charge/discharge potentials as the reference for each electrode.

DSC was performed using a DSC 2920 (TA Instruments, New Castle, DE). Samples were loaded under dry, room air atmosphere and sealed in aluminum sample pans to prevent liquid/vapor loss at high temperatures. Measurements of the cycled electrodes were made by punching out three small ( 0.125 in dia) discs from the larger T-cell disc and sealing them in the DSC pans either with or without liquid solvent/electrolyte. These small sample discs were loaded with the metallic current collector down so that the Li intercalated coatings did not touch the aluminum pans, which could have resulted in alloying. This arrangement required the removal of the coating on one side of the double-sided cathodes prior to these measurements. The mass normalized data were calculated based on the total mass of the measured sample including active material, electrolyte and any metal current collector backing for the electrodes. Every effort was made to control the amount of electrolyte/solvent liquid in each sealed pan, but the small quantities involved made exact control impossible, resulting in variations in the relative amount of the liquid and subsequent variations in the relative electrolyte/solvent thermal signature.

\section{RESULTS}

\section{Uncycled Electrodes}

Uncycled electrode materials were measured in the "as received" dry state, in the presence of solvent and in the presence of solvent/salt electrolyte. The dry "as received" samples showed the PVDF $175^{\circ} \mathrm{C}$ melt transition with weak exothermic decomposition reactions above $350^{\circ} \mathrm{C}$. The addition of the solvent and the electrolyte lowered the PVDF melt transition and showed characteristic decomposition endotherms in the $200^{\circ} \mathrm{C}-300^{\circ} \mathrm{C}$ region.

\section{Cycled Anodes}

The cycled anodes were removed from the T-cell, rinsed/dried and measured in the DSC. Figure 1 shows the DSC data up to $400^{\circ} \mathrm{C}$ for each Li level. Exothermic reactions were seen in the $250^{\circ} \mathrm{C}-400^{\circ} \mathrm{C}$ range for Li levels of 0.5 or greater. However, little or no thermal activity was seen for the 0.0-0.3 Li levels. The exotherms increased in magnitude with increasing Li content of 0.5 or greater, starting with a peak near $370^{\circ} \mathrm{C}$ and shifting to lower temperatures for the two highest $\mathrm{Li}$ levels. This activity suggests that the intercalated carbon is reacting directly with the PVDF. No thermal activity was seen for any of the anodes at temperatures below $250^{\circ} \mathrm{C}$.

The effect of adding EC:PC:DEC solvent to the anodes is shown in Figure 2. No thermal activity was seen below $300^{\circ} \mathrm{C}$ for any $\mathrm{Li}$ level, other than the characteristic solvent endotherms. Above $300^{\circ} \mathrm{C}$, exothermic reactions occurred only for Li levels of 0.5 or greater, increasing with 
the $\mathrm{Li}$ content, as was seen for the rinsed/dried anodes. However, the exotherms were now broader with a peak around $375^{\circ} \mathrm{C}$. This behavior was qualitatively similar to that seen in the rinsed/dried anodes indicating that the solvent is not contributing significantly to this reaction.

The effect of adding the EC:PC:DEC/LiPF 6 electrolyte is shown in Figure 3. Significant exothermic reactions occurred in the low-temperature regime below $200^{\circ} \mathrm{C}$, with double exotherms centered around $100^{\circ} \mathrm{C}$ and $150^{\circ} \mathrm{C}$. The-magnitudes of the lower temperature peaks were not correlated with the Li levels. Other work has attributed these reactions to an electrolyte/SEI layer interaction $[5,6]$. We believe that this interpretation is correct since no reactions are observed for the "as received" anodes. However, a more accurate interpretation is that of a reaction of the $\mathrm{LiPF}_{6}$ in the electrolyte with the SEI layer that does not directly involve the solvent. This $\mathrm{SEI} / \mathrm{LiPF}_{6}$ reaction can contribute significantly to the thermal runaway behavior of the cell. The thermal release beginning near or below $100^{\circ} \mathrm{C}$ can drive the cell temperature higher where further reactions in the $200^{\circ} \mathrm{C}-300^{\circ} \mathrm{C}$ intermediate-temperature and $300^{\circ} \mathrm{C}-400^{\circ} \mathrm{C}$ high-temperature regimes can further maintain the increasing cell temperature. Increased exothermic activity was also seen in the $200^{\circ} \mathrm{C}-300^{\circ} \mathrm{C}$ intermediate-temperature regime. An exothermic reaction was superimposed on the solvent endotherms, increasing with increasing Li level and centered on $275^{\circ} \mathrm{C}$. Since this behavior was not seen with the addition of solvent only, the $\mathrm{LiPF}_{6}$ is again indicated as being involved in an exothermic reaction, probably involving the PVDF and possibly the solvent as a transport medium. Exothermic reactions in the $300^{\circ} \mathrm{C}-400^{\circ} \mathrm{C}$ high-temperature regime were very similar to those seen for the solvent only runs. Peaks near $375^{\circ} \mathrm{C}$ were seen only for the high $\mathrm{Li}$ level materials. This indicates that the $\mathrm{LiPF}_{6}$ salt was not involved in these high-temperature reactions. Thus, these reactions were primarily Li/PVDF interactions. The involvement of PVDF in these intermediate and high-temperature reactions was verified by dissolving the PVDF from the cycled films and measuring the active material only. The low-temperature SEI interactions were still present but there was no exothermic reactions at higher temperatures even in the presence of the electrolyte.

\section{Cycled Cathodes}

The cycled cathodes, rinsed/dried as described earlier, showed weak exothermic reactions increasing with decreasing $\mathrm{Li}$ content over a temperature range of $250^{\circ} \mathrm{C}-350^{\circ} \mathrm{C}$. The addition of the EC:PC:DEC solvent resulted in significantly increased exothermic reactions for the cathodes with 0.75 and $0.5 \mathrm{Li}$ levels as shown in Figure 4. The exotherms increased in magnitude and occurred at lower temperatures with the decreasing Li levels. However, the fully discharged $\left(\mathrm{Li}_{1.0}\right)$ cathode showed only the charactênstic solvent endotherm. The cycled cathodes in the presence of the EC:PC:DEC/LiPF 6 electrolyte, as seen in Figure 5, showed similar behavior. Again, the fully discharged cathodes showed no thermal activity over the entire temperature range. The cathodes with reduced $\mathrm{Li}$ level showed significantly enhanced exothermic reactions in the presence of the EC:PC:DEC solvent, independent of the presence of the $\mathrm{LiPF}_{6}$ salt. We believe that the removal of the $\mathrm{Li}$ from the $\mathrm{LiCoO}_{2}$ crystal structure which results in an increase in the oxidation potential of the active material results in enhanced solvent decomposition at the crystal/solvent interface, possibly including interaction with the PVDF polymer. Thus, the cathode contribution to thermal instability in the cell only occurs after the cell has already reached high temperatures $\left(>200^{\circ} \mathrm{C}\right)$ and is not of concern for discharged cells. 


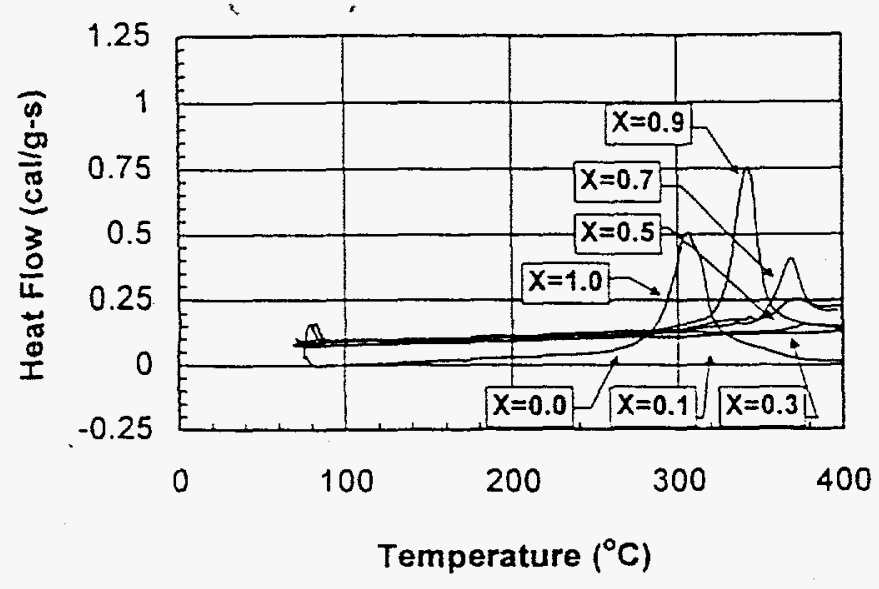

Figure 1. Cycled anodes, rinsed/dried.

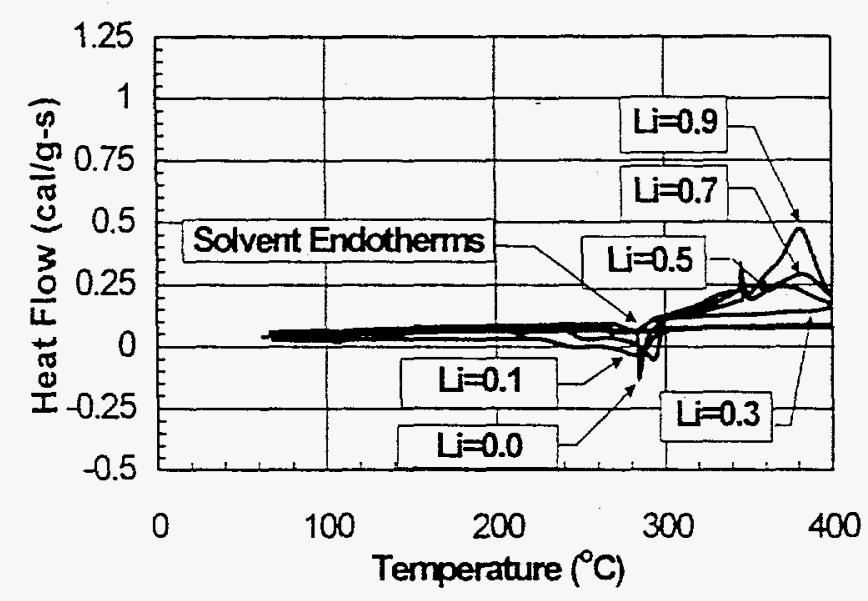

Figure 2. Cycled anodes with solvent.

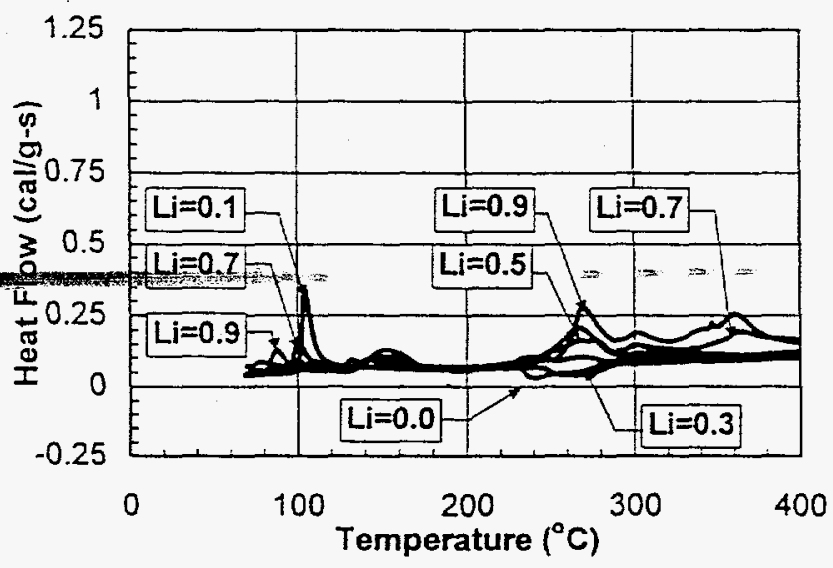

Figure 3. Cycled anodes with electrolyte.

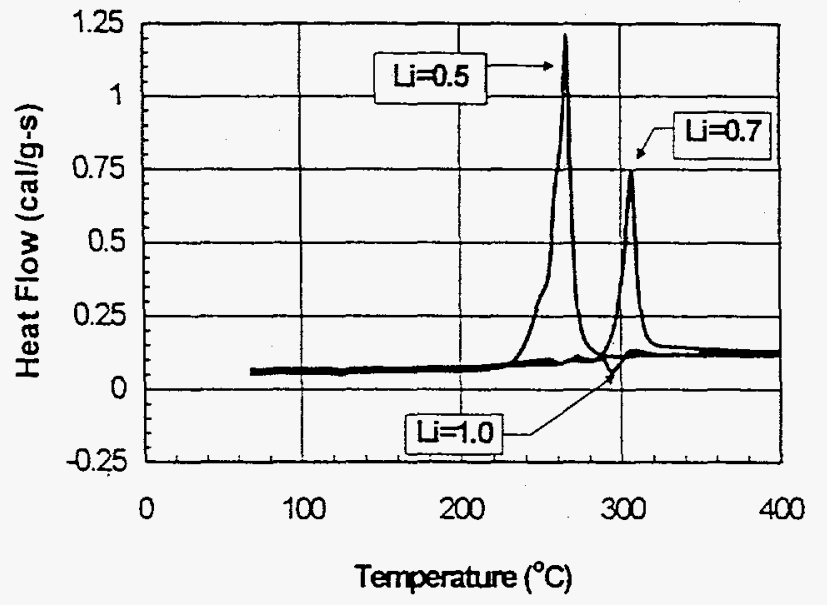

Figure 4. Cycled cathodes with solvent.

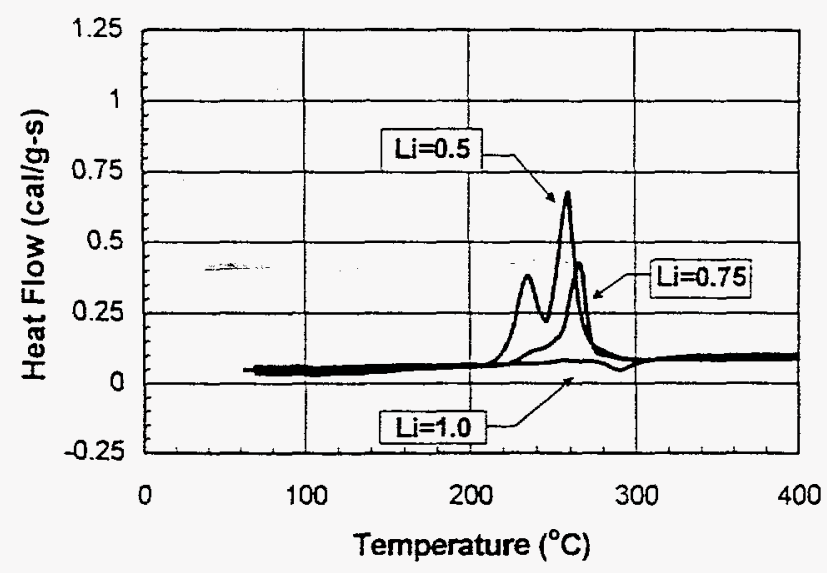

Figure 5. Cycled cathodes with electrolyte.

\section{CONCLUSIONS}

Thermal analysis of the anodes and cathodes in these cells has shown that there are three regions of thermal activity. In the low-temperature regime $\left(75^{\circ} \mathrm{C}-200^{\circ} \mathrm{C}\right)$, cycled anodes showed 
an exothermic SEI layer reaction which did not involve the PVDF binder. The magnitude of the exotherms did not correlate with the $\mathrm{Li}$ level. These reactions only occurred with the presence of $\mathrm{LiPF}_{6}$ in the solvent and did not directly involve the $\mathrm{EC}: \mathrm{PC}: \mathrm{DEC}$ solvent. In the intermediate temperature regime $\left(200^{\circ} \mathrm{C}-300^{\circ} \mathrm{C}\right)$, the cycled anodes underwent an exothermic reaction $\left(275^{\circ} \mathrm{C}\right)$ superimposed on the solvent endotherms, increasing in magnitude with increasing $\mathrm{Li}$ level. The reaction again only occurred with the presence of the $\mathrm{LiPF}_{6}$ in the solvent and did not occur for the pure solvent. This reaction is believed to be a Li/PVDF interaction not directly involving the solvent. Removal of the PVDF from the cycled films eliminated the reaction and confirmed that the PVDF is a main reactant. In the high temperature regime $\left(300^{\circ} \mathrm{C}-400^{\circ} \mathrm{C}\right)$, the cycled anodes showed increasing exotherms with increasing Li level only for Li levels 0.5 or greater. Those anodes with $\mathrm{Li}$ levels below 0.5 showed little or no thermal activity under any exposure conditions. These reactions occurred for the rinsed/dried films as well as in the presence of solvent or electrolyte. Removal of the PVDF from the films eliminated the exotherms also. These results suggest that Li/PVDF is the most probable interaction occurring in this temperature range.

The cycled $\mathrm{Li}_{\mathrm{x}} \mathrm{CoO}_{2}$ cathodes showed much less thermal activity than was seen for the anodes. Exothermic reactions only occurred in the $250^{\circ} \mathrm{C}-350^{\circ} \mathrm{C}$ range and only for the nondischarged states $(x<1.0)$. The fully discharged $(x=0.5)$ cathodes showed no thermal activity over the entire $70^{\circ} \mathrm{C}-400^{\circ} \mathrm{C}$ temperature range under any exposure conditions. The addition of solvent to the cathode films greatly enhanced the exothermic reactions but no additional reactions were seen for the addition of the $\mathrm{LiPF}_{6}$ salt. We believe that the removal of the Li from the $\mathrm{CoO}_{2}$ crystal structure results in an increase in the oxidation potential of the structure that results in enhanced solvent decomposition possibly including PVDF degradation.

\section{ACKNOWLEDGEMENTS}

The authors would like to thank Mine Safety Appliances for providing electrodes and starting materials for this work. We also wish to thank Herb Case for performing T-cell measurements and Fred Reinhardt for the DSC measurements. Sandia National Laboratories is a multiprogram laboratory operated by Sandia Corporation, a Lockheed Martin Co., for the United States Department of Energy under Contract DE-AC04-94AL85000.

\section{REFERENCES}

1. A. Pud, O. E. Mikulina and G. S. Shapoval, Macromolecular Reports A32 (Suppls. 5 \& 6), 621 (1995).

2. H. Maleki, J.S. Hong, S. Al Hallaj, and J.R. Selman, Meeting Abstracts of The Electrochem. Soc., 97-2, 143 (1998).

3. J. N. Reimers and J. R. Dahn, J. Electrochem. Soc., 139 (8), 2091 (1992).

4. Y. Saito, K. Kanari and K. Takano, J. Power Sources, 68, 451 (1997).

5. A. Du Pasquier, F. Disma, T. Bowmer, A. S. Gozdz, G. Amatucci and J-M. Tarascon, J. Electrochem. Soc., 145, (2), 472 (1998).

6. J-S. Hong, H. Maleki, S. Al Hallaj, L. Redey, and J. R. Selman, J. Electrochem. Soc.,145 (5), 1489 (1998).

7. Z. Zhang, D. Fouchard and J. R. Rea, J. Power Sources, 70, 16 (1998).

8. U. von Sacken, E. Nodwell, A. Sundher and J. R. Dahn, J. Power Sources, 54, 240 (1995). 